\title{
The Cooperative Development and Strategy
}

\author{
Adriano Dias de Carvalho*
}

Received: March 02, 2012 Accepted: April 19, 2012 DOI: 10.5296/ijafr.v2i1.1563

\begin{abstract}
Cooperatives are organizations with great potential and possibilities to stir social change. In face of economic difficulties, cooperative is an option to take advantage of the existing productive power and, once authorized to operate as financial institution, they can face the economical instability and work to improve people welfare. This paper is a study on possible emergent strategy in a credit cooperative in the south of Minas Gerais, aiming at proposing an introduction of a competitive strategy to the organizational development. It was observed as a theoretical referential the origin and the development of cooperativism, some ways of management which aim at strategic planning.

World tendency clearly shows that, even though the cooperativism segment has become one of the most developed segments in the last years, this system is still trying to solve problems of strategic formulation and organizational placement, aiming at developing a segmented financial market, much more competitive.

To propose of a strategy to the cooperative studied, gain importance when we analyze the financial market context, since this segment is one of the most regulated and organized on the world. At the end of the study, are detect the main points that can collaborate significantly to the development of this cooperative, showing as proposal suggestion of management pacing and strategic development.
\end{abstract}

Keywords: Cooperative development; strategy, institutions

\footnotetext{
* Master of Business Administration and Strategic Management, Organizational. Specialist in Financial Accounting and Auditing, a professor of FATEC - Faculty of Technology and Mococa UNIFEG - University Center of Educational Foundation Guaxupé. Professor at the University Center Unifae Associated Colleges of Education FAE.
} 


\section{Introduction}

Cooperatives are a particular form of entrepreneurial organization, but in this society, at the end of the year, operating income obtained may present residual or operating losses, distributed in proportion to the volume of operations of each of the partners. In a cooperative, there is no employer. A general assembly, council or group of representatives, composed by members of its workforce, manages and controls the business. By its very nature, a cooperative doesn't allow individualistic culture inside of itself. It is a group of people looking for common economic, social and educational growth and avoiding the exploitation of the weak by the strong.

Cooperative movement is a wide topic that deserves attention, for its economic and social relevance. The human society is marked by the prevalence of a minority, institutionalized by social and cultural force, who owns the capital or the know-how, over the people.

The growth of cooperatives faces many weaknesses brought by other organizations competitive pressure, which can present serious threat to cooperatives survival in the long run. Currently, credit cooperatives act specifically on lending; finding no ideological constraints, for wherever there is a cooperative, there is contribution to the development of society as well. So there are cooperatives in countries like Brazil, Russia, Japan, USA, Cuba, China, and its expansion has occurred in many parts of the world.

Through an exploratory participant research, this study aims at reflecting on the true cooperative context and at assessing the strategic management model used and the possible difficulties in the strategic development, to contribute to the development of this research.

\section{Formulation of the Problem}

Each cooperative has the autonomy to focus on a particular segment, adopt a particular strategic management model, and adapt itself to each environment (country or region). Some factors are essential to achieve good result and avoid the end of cooperative will. It starts with the assumption that the cooperatives under study do not maintain formal strategy. However, as with any other organization, emerging strategies can be found even if they are not clearly stated. This picture leaves a question: What are the strengths and weaknesses of the cooperative management model? What is the impact, positive or negative, of the emerging strategies?

The alleged reasons for the problems of the credit cooperatives are many, starting with the lack of resources, through lack of professionalism among leaders, lack of capitalization, financial vulnerability, bureaucratic structure, intense competition in an increasingly globalized market, ending with low participation of cooperative members in the assemblies.

Wright, Kroll and Parnell (2000) point out that a company can adopt a corporate strategy of growth when resources are available or there are opportunities to increase its market share. For Christensen (1999), the company must develop a methodology to identify attractive business opportunities that add value and enrich the corporate strategy. In order to do this, Porter (1999) states that companies must transform successful strategy principles into a diversification strategy.

As cooperatives face competitive markets, this paper is an attempt to create an alternative form of management of cooperatives, which can serve as a viable strategic plan to achieve 
both conscious development and sustainability.

\section{Construction of Assumptions}

The decision to focus on the study of credit unions is directly related to the importance that this sector represents in Brazil and worldwide. This research highlights the study of the influence of increasing opportunities, while maintaining influences growth of authors, such as Jensen (1986). Cooperative responses to the environment in which they operate in have been slow, mainly because strategic decisions are taken collectively in sporadic meetings, which in general have low attendance of members (ANTONIALLI, 1998). Slack (2000) states that strategy guides the organization in the quest for global, economic, social and political positioning.

This study seeks an evaluation of the performance and perception of managers and staff, identifying strengths that might be essential for both growth and development of strategic activities in cooperatives, as well as weaknesses that have to be neutralized or discouraged. For this purpose, this paper assumes that:

Some cooperatives do not have a formalized strategy for action, shared with its members;

$\checkmark$ Some cooperative members have low involvement and do not have enough knowledge of the management practices conducted in the cooperative, which leads to various problems;

Some Cooperatives develop their strategic processes through emerging strategies, adjusted to regional changes in environment, which are also closely correlated to changes in management.

\section{Objectives}

In micro and small credit unions, business owners operate in a simpler, less bureaucratic way. Considering this, this paper aims;

Identifying strategic actions undertaken within the cooperatives and evaluating management models adopted, their degree of formalization and the importance of emerging strategies;

Evaluating the importance of leadership and of organizational culture power;

Identifying strengths and opportunities that may be explored by organizations, as well as detecting and minimizing weaknesses and threats, within the financial landscape;

\section{Theoretical}

\subsection{The Cooperative}

The historical aspects involving the registered cooperatives date back at least 152 years. The idea is quite old, but the ideals and attitudes persist today. The essence of cooperativeness has changed little since the founding of the first cooperative in 1844. Changes to this are not relevant. (PINHO, 1999).

The Cooperative originated in England. As the wool industry prospered and workers demanded better working conditions and wages, a small group of weavers, who couldn't get the salaries they considered fair, met to find a way to improve their precarious economic situation. After much discussion, they decided to create their own means of action through mutual aid, so they opened a cooperative store. The store was the spark for a project called "Rockdale Equitable Pioneers Society" (Carencro, 1981). 


\section{Mll Macrothink}

International Journal of Accounting and Financial Reporting

ISSN 2162-3082

2012, Vol. 2, No. 1

During one year, twenty-eight weavers saved to get the capital and, in 1844, They opened the cooperative store in Rockdale, Lancashire, England (Pinto, 1999). The Society of Pioneers of Rochdale Probos code contained the principles regarding the structure and functioning of the consumer cooperative and produced a way to mitigate the precarious conditions they members went through, provide means of survival through successful movements, create an association of people around the world. (Amodeo, 1999).

Cooperation among people has existed since ancient times and it has always been associated with the survival of mankind. Greate examples of cooperation between people can be found in ancient Egypt, the Babylonian Empire, Greece, China and America. Economic cooperation was found in the sixteenth century, with Plockboy, which idealized the "full cooperation" of workers, and Jonhn Bellers, who sought to organize "cooperative colonies", which produce and sell products, thus eliminating middlemen profits.

The idea of the cooperative crossed the oceans and came to America in the first three decades of the twentieth century. It was developed greatly in the new continent and came to Brazil around 1932.

The cooperative ideal has spread throughout the world and now it is present in practically all sectors of the economy. It is accepted and recognized in most countries as the most appropriate, participatory, equitable, democratic business formula and it is widely employed to meet specific needs and interests of the population. The importance of further study in this sector is based on understanding, analyzing and studying strategies that are being used to grow considerably, thus providing an option for success and minimize disparities in obtaining results.

Mutual Credit Union, as well as the entire cooperative system, is made up of people whose guidelines are set by the law. Cooperatives are legally established everywhere in the world with the purpose of fostering socio-economic and educational development of society by providing it with financial services. Based on the needs of its members and on the general common interest, a cooperative fills a gap in the market, offering personalized services, since the members of a cooperative form a homogeneous public.

\section{Methodology}

Cooperative members have the right to: take part in general meetings; discuss and vote on matters they are dealing with ; choose by voting the members of the Board; resign, when it suits them; request written information about the Cooperative businesses as deemed necessary; and do businesses with other companies, as it is the cooperative goal..

This case study is carried out with intensive analysis of a coffee cooperative, seeking to gather as much as possible information, in order to learn the totality of the cooperative situation (Bruyne, 1982). In order to achieve this various methods are applied: interviews, participant observation and field studies (Hamel, 1993).

Lodi (1981) states that the interview is essentially a method of gathering information that coexists with other two other well known methods: observation and documentation. The interviews were performed by sampling intentional nature of qualitative interviews with directors and employees, in order to capture important details about the process of formulating the cooperative strategy, its management mode, its analysis of opportunities and 
threats and its analysis of self-management strategy. These interviews were evaluated by the descriptive analysis method.

A semi-structured interview was applied to some employees, directors and the supervisory board. The questions that compose the interview form contain semi-structured questions about: the SWOT analysis model (Strong and Weak points, Opportunities and Threats); administrative problems; the strategy formulation process; and participation of members. The SWOT model detects strengths, weaknesses, opportunities and threats that may affect the organization. It is widespread because, because it's efficient and easy implemented, as noted by Ghemawat (2000). This model was first developed in business schools in the USA, during the sixties. Its goals focus on the combined studies of the market forces and the profile of the organization, which should assess the degree of difficulty faced by the organization. The results of the SWOT analysis can allow a particular cooperative to develop a program of really effective activities which can guide it when performing its task, as well as suggest productive sectors in which the cooperative should or should not invest.

\section{Combination of Research Techniques}

Qualitative research, proposed by Godoy (1995), seeks information or relationships to check and expand the existing knowledge on a particular subject. Qualitative research focuses on questions or topics of broad interest, which become more direct and specific in the course of the investigation.

The interview is one of the oldest procedures for obtaining data and for a long time it was the only way to get them. It replaces tests on small businesses or new tasks, where specific tests to identify the organization needs can't be devised. The interview also serves as a prove to other sources of information (Lodi, 1981).

Quantitative studies generally seek to follow strictly a predetermined plan. They are based on clearly stated hypothesis and variables that are subject to operational definition. This means to reduce the distance between the indicator and what is indicated and between theory and data.

Evaluating a company's performance is not difficult, but requires some caution, since one of the reasons that jeopardizes the performances of analysts, investors and business managers is the measure used by them to determine the company's results - earnings per share (Drucker, 1994).

The obsession with measuring performance of an organization as a whole, or as an independent business unit, is not a recent concern for investors, managers and other users. Rudimentary counting systems used in ancient times, the emergence of money as a medium of exchange, and even current evaluations motivated by mergers, acquisitions, or privatization represent some of its phases, which overlap with society's(Kaplan, 1985).

\section{Results and Discussion - The Vision of Officers and Directors}

Interviews with staff showed that $90 \%$ believe in the cooperatives in which they work, though it showed that they clearly perceive the need of organizational restructuring, which could motivate them to stay in to the organization for a longer time.

The vast majority of employees, about $90 \%$, mentioned that the elections every four years are 


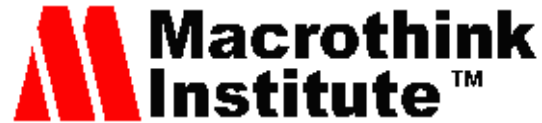

International Journal of Accounting and Financial Reporting

ISSN 2162-3082

2012, Vol. 2, No. 1

beneficial for cooperatives, since this is the best way to continually renew the board of directors, electing reliable people who can develop new ideas within of cooperatives. Moreover, if the board develops a good job, it can be reelected. This view is heavily criticized by authors such as De Masy (1980), Lauschner and Schweinberger (1989), since these authors believe that this democratic model tends to elect the who are trusted by the cooperative associates, even if they are not necessarily the most qualified to manage and or control it properly.

From the perspective of employees, $80 \%$ of them stated that the cooperative environment improved after the last elections, but, environment during the elections, it had disruptions caused by individual interests. In this sense, Schulze (1987) states that, if there is or not prior registration of individual candidates or slates, when the election is held in the course of the General Assembly, the confrontation of opposing groups will always traumatic for the cooperative. Cooperatives Internal politics, for $12 \%$ of the employees, is ruled by personal interests of individuals or of groups who aims at taking control of the cooperative. Morgan (1997) states that this selfish politics makes some associates leave the cooperative, and that the conception of cooperatives as political systems, being forced to political agreements based on personal interests, conflicts and power, which spread through the entire body of the organization and eventually become the center of attention, brings countless interpersonal intrigues.

For $10 \%$ of employees, the main problems in the cooperatives relate to the lack of resources for investment in social areas. Cooperatives have also other difficulties, pointed out by employees, such as: lack of participation of the directors, lack of sufficient technology to cope with the number of active and inactive associates. Some authors, such as Jank (1997) and Yin (1994), also mention these deficiencies, among others, as factors of threat and structural problems in most of the cooperatives. Employees also were asked about self-management, i.e., the cooperative members themselves managing one another, and the professionalization of management. All employees declared for the professionalization of the leaders, but there were differences on self-management.

The directors were asked to express their opinion about the environment in which the cooperatives are situated. They pointed out, in an external analysis, their opportunities and threats, and from an internal analysis perspective, the strengths and weaknesses of the organization. Thus, the following information was collected:

\section{Environmental Threats}

The main points highlighted were non-payment, competition with other banks, lack of resources and the amateurishness of some leaders.

\section{Environment Opportunities}

Operations of credit with low interest rates have been identified as opportunities. Taking advantage of partnerships with Development Banks for special funds gives the segment agility and strength.

"The policy adopted by the banks to not favor small customers makes them seek the cooperative to join it and it strengthens the system" (interview extract) ... "The big banks are not interested in the small account holders. Therefore, the cooperatives take this role, 


\section{Macrothink}

International Journal of Accounting and Financial Reporting

ISSN 2162-3082

2012, Vol. 2, No. 1

welcoming these customers, so they can come together and create large business opportunities (interview extract)."

For some directors, "The opportunity lies in the companies' lack of working capital, making them captive of the financial system." (Interview extract).

\section{Strengths}

The strengths mentioned in the interviews include: easiness to talk to, personalized and fast services, easy access to credit, non-bureaucratic systems, and partnerships with development banks.

\section{Weaknesses}

The weaknesses mentioned include: the lack of advertising, lack of resources, lack of credibility, lack of commitment of directors in cooperative, low participation of cooperative members in assemblies, lack of interest on the cooperative by its members and high interest rates.

For some managers, "cooperative members do not have an acceptable participation in the cooperative. Many of them seek to benefit their own interests in the cooperative and do not cultivate the ideals of unity and common good."

When asked about the participation of the cooperative members in the assemblies, all the directors were unanimous in saying that there is not much participation. Concerning the electoral process in cooperatives, some directors revealed that the proposals for election are often vague and are not based on a specific plan.

Decisions are made within the cooperative by the Board, although some directors often miss meetings. Besides that, some cooperative members are not committed with the board. When the board doesn't have a good relationship with the members, the former rules in isolation, and the last don't state their opinion about the cooperative decisions. 


\section{Macrothink \\ International Journal of Accounting and Financial Reporting \\ ISSN 2162-3082 \\ 2012, Vol. 2, No. 1}

Summary of main topics highlighted between the groups:

\begin{tabular}{|c|c|c|c|}
\hline \multirow[t]{2}{*}{ Topics } & \multirow[t]{2}{*}{ Points of convergence } & \multicolumn{2}{|c|}{ Points highlighted by only one group } \\
\hline & & directors & Members \\
\hline opportunities & $\begin{array}{l}\text {-Potential to grow; } \\
\text {-Self-management by } \\
\text { the members }\end{array}$ & $\begin{array}{l}\text {-Partnerships with } \\
\text { other institutions; } \\
\text {-Strengthening of } \\
\text { the segment. }\end{array}$ & $\begin{array}{l}\text { - Elections every four } \\
\text { years with } \\
\text { representatives of } \\
\text { the members. }\end{array}$ \\
\hline threats & $\begin{array}{l}\text { - Competition, } \\
\text {-Lack of professional } \\
\text { leaders; } \\
\text {-Distortion of true } \\
\text { cooperative ideal. }\end{array}$ & $\begin{array}{l}\text {-impoverishment of } \\
\text { the cooperative }\end{array}$ & $\begin{array}{l}\text {-Lack of appropriate } \\
\text { technology. }\end{array}$ \\
\hline strengths & $\begin{array}{l}\text {-Search for common } \\
\text { goals; } \\
\text { •Agility in service; } \\
\text { •non bureaucratic } \\
\text { system }\end{array}$ & $\begin{array}{l}\text {-Integration of the } \\
\text { members; } \\
\text {-Personalized } \\
\text { service; } \\
\text {-Ease access to } \\
\text { credit. }\end{array}$ & - Self-management \\
\hline weaknesses & $\begin{array}{l}\text {-Scarcity of resources; } \\
\text { - Lack of commitment } \\
\text { of directors in the } \\
\text { Cooperative; }\end{array}$ & $\begin{array}{l}\text {-Lack of } \\
\text { professional } \\
\text { managers; } \\
\text {-Lack of interest in } \\
\text { the Cooperative by } \\
\text { the members; } \\
\text {-Low member } \\
\text { participation in } \\
\text { meetings; } \\
\text {-Lack of a strategic } \\
\text { plan, } \\
\text {-Lack of a suitable } \\
\text { administrative } \\
\text { structure. }\end{array}$ & $\begin{array}{l}\text {-Difficulties in the } \\
\text { transition of offices; } \\
\text {-personal interests; } \\
\text { •High number of } \\
\text { inactive members. }\end{array}$ \\
\hline
\end{tabular}

Source: Compiled by author

\section{7 - Conclusions}

The analysis of the results, acquired by the application of the methodology supported by the theoretical framework, allows us to make the following considerations in order to contribute to the fulfillment of the objectives.

Each cooperative is free to develop its own strategic plan, focusing on areas that fit its needs. The lack of a monitoring system brings lack of credibility to the system. Perhaps, the greatest challenge to the cooperative model is to develop and adapt a model of cooperative 
management, giving priority to economic and social equality in purely capitalist countries.

The hypothesis that there is a formalized strategic planning in most cooperatives was confirmed, and emerging strategies are neither achieving success in their implementation, as they are not correctly evinced, nor are shared among members of the board, this way, each winning slate emphasizes their promises when in office, which causes discontinuity in tasks proposed by predecessors. This fact strongly influences the cooperatives to not last for long.

The cooperative, in general, is concerned with developing a management model. However, the role of cooperatives in relation to their social responsibilities is still passive. Cooperatives accommodate the demands of their members and the community, believing that, in this way, they are contributing to solving the community problems. Cooperatives still find it difficult to detect the actual needs of their members.

Professionalization, in the opinion of all of the interviewed, is a viable approach to solve the administrative problems of cooperatives, so there is always a concern in hiring well-qualified people to serve in management positions.

The external analysis shows that the Cooperative has good opportunities for growth and fund raising, which will certainly strengthen the segment.

Concerning the threats due to the increasing competition in financial markets, cooperatives appear to be vulnerable to the demands of this sector. Lack of professionalism of leaders, lack of investment in high technology and the possible distortion of the true cooperative ideal by some cooperative directors and selfish members, can weaken and influence directly the whole system.

With self-management, differing political interests may also occur, in which some unprofessional elected managers are unable to make decisions to avoid particular threats, which are often imposed by competitive environments. Then, decisions are made in sporadic meetings, with, low participation of members.

Through an internal analysis, it was concluded that the main strengths are the pursuit of common goals, members' integration, agile and personalized service, ease of access to credit system and low level of bureaucracy. The provision of services has become a key for Cooperatives: once it lacks advanced technology, it gives the client freedom to talk with managers.

On the other hand, the main weaknesses identified are: bad administration done by some amateur directors; the existence of internal conflicts among the directors and members; lack of interest and low participation of members in assemblies; lack of commitment of directors with the cooperatives; lack of a formal strategic plan. These points confirm this paper hypothesis $\mathrm{k}$.

The key variables above were totally or partially agreed and highlight major points that should be seen as priority by current boards. Initially, cooperatives should establish an organizational philosophy to guide the organization future. One of the first measures to be taken is to state the cooperative mission, its reason of existence. The organization is better conducted when its mission is shared with directors, members and employees. In each disagreement, personal interests can be revealed, especially in the search of power, since ideologies are different, but the commitment to defend collective interests must prevail in 
every office. Amateurism and improvisation don't have space any more in business models. It is necessary to eliminate paternalistic trends in organizations, solve internal rivalries, and avoids political interference, which can lead to important differences and to lose administrative organization.

However, the question remains: will the cooperative model survive in an increasingly competitive capitalist individualist environment, whose interests outweigh the interests of mutual help and equality of social conditions? Other factors should be sought in order to increase the benefits of the cooperative sector in response to this question, since this study dealt with only a few points. It is suggested that further research should be conducted to expand knowledge about business models and strategic continuity.

\section{References}

Amodeo, NBP (1999) Cooperatives and agroindustrial competitiveness challenges.UFRRJ, (1999). PP 318.

ANTONIALLI, LM (2000) Model management and strategies: the case of two mixed cooperatives of milk and coffee from Minas Gerais. FEA / USP, (2000). PP 163-175.

Ansoff, H. Igor and MCDONNELL, Edward J. (1984) Strategic Management implanting, Pretice Hall (1984) PP 54-87.

Bialoskorski NETO, S. (1997) Agribusiness Management Cooperative. In: Battle, M. Agribusiness Management, (1997) PP 148-153.

Bruyn, P. H. and SCHOTHEETE, M. (1982) Dynamics of social science research: the poles of methodological practice. Atlas (1982). PP 25-57.

Carneiro, P. P. (1981) Cooperative: the principle and driving force of the existential-social work. Fundeci, (1981). PP 78-82.

RIGHT, Samuel C., PETER J. Paul. (1993) Strategic Management - Planning and Implementation of the Strategy. Makron Books, (1993). PP 13-27.

CHRISTENSEN, H. K. (1999) Corporate strategy: managing a set of businesses. In: Practical: strategy. 2th. Campus, (1999). PP 67-99.

CHIAVENATO, Idalberto. (1998) Human Resource Management. 3. th. Atlas (1998) pp. 97-103.

DAVIDSON, W. (1988) Retailinf Management, NY: John Wiley, (1988) pp. 35-39.

A Masy, CR (1980) Critical analysis of the cooperative legislation in Brazil. Perspective Economy, vol. 8 (cooperative series) (1980) PP 49-53.

Carvalho, Adriano Dias (2003) The Strategy of Relationship Marketing in

Credit Unions. Magazine Academic Interaction, (2003) PP 145-147.

Drucker, Peter Ferdinand. (1994) The age of social transformation. The Atlantic montly, v.274.n 5, (1994) PP 83-85.

Fischmann, A.A, ALMEIDA, M.I.R. (1991) estratégico.Atlas Planning, (1991) PP 25-26.

Foucault, M. (1993) Microphysics of power. Grail. (1993) PP 45-46. 


\section{Macrothink}

International Journal of Accounting and Financial Reporting ISSN 2162-3082 2012, Vol. 2, No. 1

Ghemawat, P. (2000) The strategy and the business landscape: text and casos.Boockman, (2000) PP 221-223.

Ginsberg, A. (1984) Operationalizing organizational strategy: Toward an interrogative framework. Academiy of Management Review (1984) PP 548-557.

Godoy, Arild Schmidt. (1995) Introduction to qualitative research and its possibilities. Journal of Business Administration. Sao Paulo (1995) PP 48-49.

Hamel, G., and Prahalad, C. K. (1993) "Strategic intent", Harvard Business Review, May-June, (1993) PP 67-68.

Jensen, Michael C. (1986) Agency costs of free cash flow, corporate finance and takeovers. American Economic Review. (1986) PP 323-339.

Jank, M. S. (1997) Schedule days for cooperatives, the agricultural sector, entities have to deal with fierce competition and need to review their rules. Folha de Sao Paulo. Notebook of Economics, (1997) PP 85-87.

Kaplan, Robert S. and JOHNSON, R. (1985) Relevance Lost. Massachusetts: Harvard Press, (1985) PP 83-84.

Kotler, Philip. (2000) Marketing management: the issue of the new millennium. Trad. Bazan Technology and Linguistics, 10 th. (2000) PP 91-92.

LAUSCHNER, R. Scheinberg, G. A. (1989) Efficiency y la effectiveness of company y co-operative structure of power. Economic Outlook. (1989) PP 11-26.

LODI, John Bosco. (1981) The theory and prática.Pioneira Interview, (1981) PP 22.

McCONNELL, John J., Servaes Henri. (1995) Euity ownership and the two faces of debt. Journal of financial economics. (1995) PP 131-157.

Mintzberg, H., Ahlstrand, B., Lampel, J. (2000) Strategy Safari: a

route through the jungle of strategic planning. Bookman, (2000) PP 116.

Morgan, Gareth. (1997) Images of Organization. Atlas (1997) PP 61-62.

PANKAJ, Ghemawat. (2000) The business scenario. Bookman, (2000) PP 55.

PETERS, T. WATERMAN, H. (1999). In Search of Excellence: Lessons from

America's Best Run Companies. New York: Harper an Row (1999) PP 74-78.

PINE, Djalma Reboucas de Oliveira. (1999) Manual for the Management of Cooperatives: a practical approach. Atlas (1999) PP 48-49.

Porter, Michael E. (1979) The Structure Within Industries and companies' performance. Review of Economics and Statistics. (1979) PP 214-219.

Prahalad, C. K., Hamel, Gary. (1990) The Core Competence of the Corporation.

Harvard Business Review. (1990) PP 55-56.

Schulze, E. (1987) Structure of power cooperatives. Economic Outlook. Vol 22

(Cooperative Series) (1987) PP 216-217.

Senge, P. M. (1998) Communities of leaders and learners. HSM Management. Savana. (1998) pp. 56-58. 


\section{Macrothink}

International Journal of Accounting and Financial Reporting

ISSN 2162-3082 2012, Vol. 2, No. 1

Slack, N. (1197) Management of production. Atlas (1997) PP 211-212.

WRIGHT, P., Kroll, M., Parnell, L. (2000) Strategic management: concepts. (2000) PP 307-308.

Yin, R. K. (1194) Case study research: design and methods. 2 th. California: Sage Publishers. Ed London: Sage Publications, (1994) PP 105-106. 